\title{
Lentibacter algarum gen. nov., sp. nov., isolated from coastal water during a massive green algae bloom
}

\author{
Zhao Li, Zhe Qu, Xiuming Zhang and Xiao-Hua Zhang \\ College of Marine Life Sciences, Ocean University of China, Oingdao, PR China
}

Correspondence

Xiao-Hua Zhang

xhzhang@ouc.edu.cn

\begin{abstract}
Two novel Gram-stain-negative, aerobic strains $\left(Z X M 100^{\top}\right.$ and ZXM098) were isolated from seawater in the coastal region of Qingdao $\left(36.027^{\circ} \mathrm{N} 120.184^{\circ} \mathrm{E}\right)$, China, during a massive green algae bloom. Cells were ovoid to irregular short rods and lacked flagella. Poly- $\beta$-hydroxybutyrate was accumulated. Cells did not contain bacteriochlorophyll $a$. The isolates grew at $\mathrm{NaCl}$ concentrations of $3-9 \%$ and $22-28{ }^{\circ} \mathrm{C} . \mathrm{C}_{18: 1} \omega 7 c, \mathrm{C}_{18: 0}$ and $\mathrm{C}_{16: 0}$ were the major fatty acid components. The polar lipids of $\mathrm{ZXM} 100^{\top}$ were phosphatidylglycerol, phosphatidylethanolamine, phosphatidylcholine, a single lipid and an unidentified aminolipid. The predominant isoprenoid quinone of $Z X M 100^{\top}$ was Q-10. Phylogenetic analysis based on $16 \mathrm{~S}$ rRNA gene sequences showed that strains belonged to the family Rhodobacteraceae. Based on the results obtained in this study, strain $Z X M 100^{\top}$ was considered to represent a novel species in a new genus, for which the name Lentibacter algarum gen. nov., sp. nov. is proposed. The type strain is $Z X M 100^{\top}\left(=\right.$ LMG $24861^{\top}=$ CGMCC $\left.1.10234^{\top}\right)$; the DNA G + C content of the type strain is $54.6 \mathrm{~mol} \%$.
\end{abstract}

Members of the family Rhodobacteraceae, classified within the class Alphaproteobacteria, are exclusively marine or hypersaline, with characterized isolates demonstrating salt tolerance (Buchan et al., 2005); at the time of writing, the family contained 84 phenotypically, metabolically and ecologically diverse genera. Their global distribution seems to be related to oceanic water masses and their environmental and biogeochemical properties (Gao et al., 2006). Two novel bacterial strains, designated $Z X M 100^{\mathrm{T}}$ and ZXM098, were isolated from seawater samples in the coastal region of Qingdao, China, during a massive green algae bloom. The aim of the present study was to determine the exact taxonomic position of strains $\mathrm{ZXM100}^{\mathrm{T}}$ and $\mathrm{ZXM} 098$ by a polyphasic taxonomic approach.

A seawater sample was collected from the coastal region of Qingdao $\left(36.027^{\circ} \mathrm{N} 120.184^{\circ} \mathrm{E}\right)$, China in June 2008, during a massive green algae (Enteromorpha prolifera) bloom. The sample was diluted with sterile saline and spread onto marine agar 2216 (MA; Difco) plates incubated at $28{ }^{\circ} \mathrm{C}$ for 7 days. Strains ZXM100 ${ }^{\mathrm{T}}$ and ZXM098 were purified by streaking three times on MA. Cultures were maintained on MA plates and stocks were kept in sterile

Abbreviations: Bchl, bacteriochlorophyll; $\mathrm{PHB}$, poly- $\beta$-hydroxybutyrate.

The GenBank/EMBL/DDBJ accession numbers for the $16 \mathrm{~S}$ rRNA gene sequences of Lentibacter algarum ZXM100' and ZXM098 are FJ436732 and FJ436731, respectively.

Three supplementary figures and a supplementary table are available with the online version of this paper.
$0.9 \%(\mathrm{w} / \mathrm{v})$ saline supplemented with $15 \%(\mathrm{v} / \mathrm{v})$ glycerol at $-80{ }^{\circ} \mathrm{C}$. Sulfitobacter pontiacus DSM $10014^{\mathrm{T}}$ obtained from the DSMZ (Deutsche Sammlung von Mikroorganismen und Zellkulturen GmbH, Braunschweig, Germany) was used as the reference strain and was cultured under the same conditions as $\mathrm{ZXM}^{\mathrm{T}}{ }^{\mathrm{T}}$ and ZXM098 [MA or marine broth $2216(\mathrm{MB})$ at $28{ }^{\circ} \mathrm{C}$, unless otherwise specified.

Cell morphology was determined by transmission electron microscopy (JEOL; JEM-1200EX) after cells had been negatively stained with $1 \%(\mathrm{w} / \mathrm{v})$ phosphotungstic acid. Gram and endospore staining were carried out using the standard method (Beveridge et al., 2007). The presence of poly- $\beta$-hydroxybutyrate (PHB) was assessed using Nile Blue A stain under a fluorescence microscope (BH2; Olympus) (Tindall et al., 2007).

Growth on nutrient agar (NA) and tryptone soy agar (TSA; Difco) supplemented with $3 \%(w / v) ~ N a C l$ was tested for 7 days at $28{ }^{\circ} \mathrm{C}$. Growth under anaerobic conditions was determined after incubation in a dry-seal glass vacuum desiccator on MA for 3 days at $28{ }^{\circ} \mathrm{C}$, with 10 g gallic acid and $100 \mathrm{ml} 10 \% \mathrm{NaOH}$ to consume oxygen. Halotolerance was investigated using synthetic marine ZoBell broth $[5 \mathrm{~g}$ Bacto peptone, $1 \mathrm{~g}$ yeast extract and $0.1 \mathrm{~g} \mathrm{FePO}_{4}$ in 11 modified artificial seawater (Lyman \& Fleming, 1940)] supplied with various concentrations of $\mathrm{NaCl}(0-15 \%$, w/v, in increments of $1 \%$ ); all $\mathrm{Na}^{+}$was replaced by the appropriate $\mathrm{K}^{+}$in the modified artificial seawater. The temperature range for growth was determined on MA plates incubated at $0-37{ }^{\circ} \mathrm{C}(0,4,16$, 22, 28 and $37{ }^{\circ} \mathrm{C}$ ) for 20 days. The $\mathrm{pH}$ range for growth was 
tested at $\mathrm{pH} 2-10$ (in steps of $1 \mathrm{pH}$ unit) in $\mathrm{MB}$ with citrate/phosphate buffer ( $\mathrm{pH}$ 2.0-7.0), Tris/ $\mathrm{HCl}(\mathrm{pH} 8.0-9.0)$ (Breznak \& Costilow, 1994) or sodium carbonate/sodium bicarbonate ( $\mathrm{pH} 10.0)$. Susceptibility to antibiotics was investigated on MA plates by using discs (Hangzhou Microbiology Reagent) containing different antibiotics.

Standard protocols (Tindall et al., 2007) were used to assess catalase (method 2) and oxidase activities, degradation of casein, starch, gelatin (method 2) and Tween $80(\operatorname{method} 2)$, nitrate reduction (method 1) and $\mathrm{H}_{2} \mathrm{~S}$ production from thiosulfate (method 1). The ability to hydrolyse alginate was tested as described by Smibert \& Krieg (1994). The ability to oxidize sulfite was tested as described by Pukall et al. (1999). Bacteriochlorophyll (Bchl) $a$ of cells was determined in acetone/methanol $(7: 2, \mathrm{v} / \mathrm{v})$ extracts using a TU-1810 spectrophotometer (Pgeneral) as described previously (Martens et al., 2006). Activities of constitutive enzymes, substrate oxidation, carbon source utilization and other physiological properties were determined by using the API 20E, API 20NE, API 50CH, API ZYM strips (bioMérieux) and Gram-negative MicroPlates (Biolog), according to the manufacturer's instructions, except that sterile $3 \%(\mathrm{w} / \mathrm{v})$ $\mathrm{NaCl}$ was used to prepare the inocula. For Biolog MicroPlates, seawater was used instead of $3 \%(w / v) ~ N a C l$.

The detailed morphological, physiological and biochemical characteristics of strain $\mathrm{ZXM100}{ }^{\mathrm{T}}$ and ZXM098 are given in the species description (see below) or are shown in Table 1; transmission electron micrographs of strain $\mathrm{ZXM100}{ }^{\mathrm{T}}$ are shown in Fig. 1.

Cell mass of ZXM100 ${ }^{\mathrm{T}}$ and ZXM098 was obtained from MB after cultivation at $28{ }^{\circ} \mathrm{C}$ for $72 \mathrm{~h}$ and from $S$. pontiacus DSM $10014^{\mathrm{T}}$ after cultivation for $20 \mathrm{~h}$, when all of the communities reached the exponential stage. Cellular fatty acids were prepared and analysed according to the standard protocol described in the Sherlock System (MIDI) (Sasser, 1990) with the Sherlock version 6.0 and the included database. $\mathrm{C}_{18: 1} \omega 7 c, \mathrm{C}_{18: 0}$ and $\mathrm{C}_{16: 0}$ were the major fatty acid components in both ZXM100 ${ }^{\mathrm{T}}$ and ZXM098. Detailed fatty acid compositions are listed in Table S1 (available in IJSEM Online).

Analyses of polar lipids and respiratory quinones of ZXM $100^{\mathrm{T}}$ were carried out by the Identification Service of the DSMZ and Dr B. J. Tindall, DSMZ, Braunschweig, Germany, using the two stage method described by Tindall

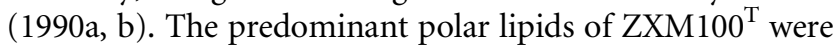
phosphatidylglycerol, phosphatidylethanolamine, phosphatidylcholine, a single lipid and an unidentified aminolipid (Figs S2 and S3, available in IJSEM Online). The predominant isoprenoid quinone of $\mathrm{ZXM100}{ }^{\mathrm{T}}$ was Q-10. The polar lipid and respiratory quinone compositions are basically consistent with those of members of related genera (Table 1; Martens et al., 2006; Choi \& Cho, 2006; Wagner-Döbler et al., 2004; Kurahashi \& Yokota, 2007).

The $\mathrm{G}+\mathrm{C}$ content of the chromosomal DNA was determined as described by Mesbah et al. (1989) using reverse-phase HPLC. The DNA G $+\mathrm{C}$ contents of strain $\mathrm{ZXM100}^{\mathrm{T}}$ and ZXM098 were 54.6 and $56.7 \mathrm{~mol} \%$, respectively.

DNA was extracted from strain ZXM100 ${ }^{\mathrm{T}}$ and ZXM098 and purified using a kit (BioDev). 16S rRNA genes were amplified by PCR using universal primers $8 \mathrm{f}\left(5^{\prime}\right.$-AGAGTTTGATCCTGGCTCAG-3') and 1492r (5'-GGTTACCTTGTTACGACTT-3') (Bosshard et al., 2000). Purified PCR products were ligated to the $\mathrm{pMD} 18-\mathrm{T}(\mathrm{TaKaRa})$ and cloned according to the manufacturer's instructions. Sequencing reactions were carried out using ABI BigDye 3.1 Sequencing kits (Applied BioSystems) and an automated DNA sequencer (model ABI3730; Applied BioSystems). Pairwise comparison showed that strains ZXM100 ${ }^{\mathrm{T}}$ and ZXM098 shared $100 \%$ $16 \mathrm{~S}$ rRNA gene sequence similarity. The near-complete $16 \mathrm{~S}$ rRNA gene sequence (1429 nt) of strain $\mathrm{ZXM100}{ }^{\mathrm{T}}$ was submitted to GenBank/EMBL to search for similar sequences using the BLAST algorithm. The identification of phylogenetic neighbours and the calculation of pairwise 16S rRNA gene sequence similarities were achieved using the EzTaxon server (http://www.eztaxon.org/; Chun et al., 2007). Sequences were aligned using CLUSTAL X1.8 (Thompson et al., 1997; the sequence alignment is available as Fig. S3). Phylogenetic trees were constructed using the neighbour-joining (Fig. 2) and maximum-likelihood (Fig. S1) methods with Kimura 2-state parameter model analyses implemented in the program MEGA version 5 (Tamura et al., 2007). In each case, bootstrap values were calculated based on 1000 replicates. ZXM100 ${ }^{\mathrm{T}}$ was circumscribed to the family Rhodobacteraceae on the basis of phylogenetic analysis of 16S rRNA gene sequences and showed $95.6 \%$ sequence similarity to Sulfitobacter delicatus LMG $20554^{\mathrm{T}}, 95.5 \%$ to Nautella italica LMG $24365^{\mathrm{T}}$ and 95.3\% to Sulfitobacter dubius LMG $20555^{\mathrm{T}}$ (http://www.ebi. ac.uk/Tools/msa/clustalw2/). Members of 10 genera (Sulfitobacter, Nautella, Thalassobacter, Leisingera, Roseobacter, Shimia, Marinovum, Phaeobacter, Oceanibulbus and Tateyamaria) of the family Rhodobacteraceae that showed the highest 16S rRNA gene sequence similarities (92.0-95.6\%) were chosen to construct the phylogenetic trees. However, strain $\mathrm{ZXM100}{ }^{\mathrm{T}}$ did not form a robust lineage in the phylogenetic trees with any species in the family Rhodobacteraceae, but formed a phylogenetically distinct lineage alongside related strains.

In conclusion, the proposal that strain $\mathrm{ZXM} 100^{\mathrm{T}}$ represents a novel species in a new genus based on phylogenetic analysis was supported by its differential morphological and physiological characteristics, i.e. (1) colourless colonies, (2) lack of flagella, (3) narrow growth temperature range, (4) better adaptation to acidic environments, (5) inability to oxidize sulfite to sulfate (sulfite oxidation is a very important property enabling members of the genus Sulfitobacter to be distinguished from other genera), (6) ability to reduce nitrate to nitrite, (7) a lower level of $\mathrm{C}_{18: 1} \omega 7 c$ and the presence of the unique component $\mathrm{C}_{17: 0}$ and (8) a lower DNA G $+C$ content. Other characteristics that differentiate strain $\mathrm{ZXM} 100^{\mathrm{T}}$ from members of related genera are shown in Table 1. 
Table 1. Characteristics that differentiate $Z X M 100^{\top}$ and $Z X M 098$ from members of related genera

Taxa: 1, ZXM100 ${ }^{\mathrm{T}}$ (data from this study); 2, ZXM098 (data from this study); 3, Sulfitobacter [S. pontiacus DSM 10014 (data from this study; Sorokin, 1995; Ivanova et al., 2004), S. mediterraneus DSM 12244 ${ }^{\mathrm{T}}$ (Pukall et al., 1999; Labrenz et al., 2000; Yoon et al., 2007a), S. guttiformis DSM 11458 ${ }^{\mathrm{T}}$ (Labrenz et al., 2000), S. brevis DSM 11443 ${ }^{\mathrm{T}}$ (Labrenz et al., 2000; Ivanova et al., 2004), S. delicatus LMG 20554 ${ }^{\mathrm{T}}$ (Ivanova et al., 2004), S. dubius LMG 20555 ${ }^{\mathrm{T}}$ (Ivanova et al., 2004), S. litoralis DSM 17584 ${ }^{\mathrm{T}}$ (Park et al., 2007), S. donghicola KCTC $12864^{\mathrm{T}}$ (Yoon et al., 2007a), S. marinus KCTC $12738^{\mathrm{T}}$ (Yoon et al., 2007b)]; 4, Nautella [N. italica LMG 24365 ${ }^{\mathrm{T}}$ (Vandecandelaere et al., 2009)]; 5, Thalassobacter [T. stenotrophicus DSM 16310 ${ }^{\mathrm{T}}$ (Macián et al., 2005; Pujalte et al., 2005); T. arenae DSM 19593 ${ }^{\mathrm{T}}$ (Kim et al., 2009)]; 6, Leisingera [L. methylohalidivorans DSM 14336 ${ }^{\mathrm{T}}$ (Schaefer et al., 2002; Martens et al., 2006)]; 7, Roseobacter [R. litoralis ATCC 49566 ${ }^{\mathrm{T}}$ (Shiba, 1991; RuizPonte et al., 1998; Park et al., 2007; Sass et al., 2010), R. denitrificans ATCC 33942 ${ }^{\mathrm{T}}$ (Shiba, 1991; Ruiz-Ponte et al., 1998; Park et al., 2007; Sass et al., 2010)]; 8, Shimia [S. marina KCCM 42117 (Choi \& Cho, 2006)]; 9, Marinovum [M. algicola ATCC 51440 (Lafay et al., 1995; Martens et al., 2006)]; 10, Phaeobacter [P. gallaeciensis DSM 17395 ${ }^{\mathrm{T}}$ (Ruiz-Ponte et al., 1998; Martens et al., 2006), P. inhibens DSM $16374^{\mathrm{T}}$ (Martens et al., 2006)]; 11, Oceanibulbus [Oceanibulbus indolifex DSM 14862 ${ }^{\mathrm{T}}$ (Wagner-Döbler et al., 2004)]; 12, Tatevamaria [T. omphalii KCTC 12333 ${ }^{\mathrm{T}}$ (Kurahashi \& Yokota, 2007; Sass et al., 2010); T. pelophila DSM $17270^{\mathrm{T}}$ (Sass et al., 2010)]. +, Positive; -, negative; W, weak reaction; V, varies between species and/or strains; ND, not described or data are not available for the type strain.

\begin{tabular}{|c|c|c|c|c|c|c|c|c|c|c|c|c|}
\hline Characteristics & 1 & 2 & 3 & 4 & 5 & 6 & 7 & 8 & 9 & 10 & 11 & 12 \\
\hline Colony colour ${ }^{*}$ & $\mathrm{C}$ & $\mathrm{C}$ & $\mathrm{Y} / \mathrm{Wh} / \mathrm{Br} / \mathrm{B} / \mathrm{P}$ & B & $\mathrm{Br} / \mathrm{P}$ & $\mathrm{C}$ & $\mathrm{P}$ & $\mathrm{O} / \mathrm{C} / \mathrm{B}$ & $\mathrm{B} / \mathrm{P}$ & $\mathrm{Br}$ & Wh & $\mathrm{B} / \mathrm{P}$ \\
\hline Cell shape & $\begin{array}{l}\text { Ovoid to } \\
\text { irregular } \\
\text { short rods }\end{array}$ & $\begin{array}{l}\text { Ovoid to } \\
\text { irregular } \\
\text { short rods }\end{array}$ & Rods & Rods & $\begin{array}{l}\text { Ovoid to } \\
\text { irregular } \\
\text { rods }\end{array}$ & $\begin{array}{l}\text { Rods or } \\
\text { ovoid rods }\end{array}$ & $\begin{array}{l}\text { Rods or } \\
\text { ovoid rods }\end{array}$ & Rods & $\begin{array}{c}\text { Ovoid } \\
\text { rods }\end{array}$ & Ovoid rods & $\begin{array}{l}\text { Irregular } \\
\quad \text { rods }\end{array}$ & $\begin{array}{l}\text { Coccus to } \\
\text { short rod }\end{array}$ \\
\hline Flagella & - & - & + & + & + & + & + & + & + & + & - & $\mathrm{v}$ \\
\hline PHB & + & + & + & + & $\mathrm{v}$ & - & $\mathrm{ND}$ & ND & - & $\mathrm{ND}$ & + & $\mathrm{ND}$ \\
\hline Bchl $a$ & - & - & $\mathrm{v}$ & $\mathrm{ND}$ & + & - & + & - & - & - & - & $\mathrm{v}$ \\
\hline \multicolumn{13}{|l|}{ Ranges for growth } \\
\hline Temperature $\left({ }^{\circ} \mathrm{C}\right)$ & $22-28$ & $22-28$ & $4-37$ & $4-45$ & $5-37$ & ND & $2-30$ & $15-35$ & $10-37$ & $4-37$ & ND & $4-37$ \\
\hline $\mathrm{NaCl}(\%, \mathrm{w} / \mathrm{v})$ & $3-9$ & $3-9$ & $0.2-15.0$ & $1-5$ & $0.85-8.0$ & $1.5-6.5$ & $\mathrm{ND}$ & $3-7$ & $0.1-2.0$ & $0.059-11.7$ & $1-7$ & $0.2-10.2$ \\
\hline $\mathrm{pH}$ & $2.0-9.0$ & $2.0-9.0$ & $5.0-11.0$ & $5.5-9.0$ & $\mathrm{ND}$ & $\mathrm{ND}$ & $\mathrm{ND}$ & $6-10$ & $6-9$ & $6.0-10.0$ & ND & $5.4-9.0$ \\
\hline Oxidase & + & $\mathrm{w}$ & + & + & + & + & + & + & + & + & $\mathrm{w}$ & + \\
\hline Catalase & + & + & + & + & + & + & + & + & + & + & + & + \\
\hline Sulfite oxidation & - & - & $\mathrm{v}$ & $\mathrm{ND}$ & $\mathrm{ND}$ & $\mathrm{ND}$ & $\mathrm{ND}$ & $\mathrm{ND}$ & $\mathrm{ND}$ & $\mathrm{ND}$ & $\mathrm{ND}$ & $\mathrm{v}$ \\
\hline Nitrate reduction & + & + & $\mathrm{v}$ & - & - & - & $\mathrm{V}$ & + & - & - & - & $\mathrm{v}$ \\
\hline \multicolumn{13}{|l|}{ Hydrolysis of: } \\
\hline Tween 80 & + & - & $\mathrm{v}$ & + & $\mathrm{v}$ & - & + & + & - & - & - & - \\
\hline Gelatin & - & - & $\mathrm{v}$ & - & - & $\mathrm{ND}$ & + & + & $\mathrm{ND}$ & - & - & - \\
\hline \multicolumn{13}{|l|}{ Oxidation of: } \\
\hline Citrate & + & + & $\mathrm{v}$ & - & $\mathrm{v}$ & - & + & + & + & $\mathrm{v}$ & + & + \\
\hline D-Mannitol & + & $\mathrm{w}$ & $\mathrm{v}$ & - & - & $\mathrm{ND}$ & + & - & - & + & + & + \\
\hline Maltose & $\mathrm{w}$ & $\mathrm{w}$ & $\mathrm{v}$ & - & - & ND & - & ND & + & + & - & + \\
\hline D-Glucose & + & + & $\mathrm{v}$ & - & $\mathrm{v}$ & - & + & - & + & + & + & $\mathrm{V}$ \\
\hline \multicolumn{13}{|l|}{ Major polar lipids } \\
\hline Phosphatidylglycerol & + & ND & $\mathrm{v}$ & ND & + & + & + & $\mathrm{ND}$ & + & + & + & ND \\
\hline Phosphatidylethanolamine & + & ND & + & ND & $\mathrm{V}$ & + & - & ND & + & + & + & ND \\
\hline Phosphatidylcholine & + & ND & + & ND & + & - & $\mathrm{V}$ & ND & + & + & + & ND \\
\hline Diphosphatidylglycerol & - & $\mathrm{ND}$ & $\mathrm{v}$ & $\mathrm{ND}$ & + & - & + & ND & - & - & + & $\mathrm{ND}$ \\
\hline DNA G $+\mathrm{C}$ content $(\mathrm{mol} \%)$ & 54.6 & 56.7 & $55.5-63.5 \dagger$ & $61.0 \pm 0.8$ & $56.0-59.1$ & 60.5 & $56-60$ & 57.2 & 60 & $55.7-58.0$ & 60.0 & $56.4-61.6$ \\
\hline
\end{tabular}

${ }^{*}$ Abbreviations: B, beige; Br, brown; C, colourless; P, pink; Y, yellow; Wh, white.

$\dagger$ Data for S. pontiacus DSM $10014^{\mathrm{T}}$ from Ivanova et al. (2004). 


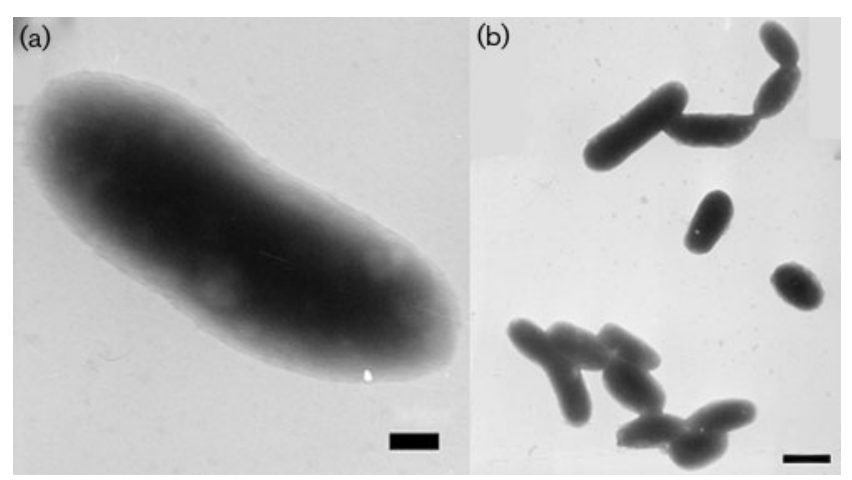

Fig. 1. Transmission electron micrographs of negatively stained cells of Lentibacter algarum ZXM100'. Bars: a, $200 \mathrm{~nm} ; \mathrm{b}, 1 \mu \mathrm{m}$.

Therefore, on the basis of the phenotypic and phylogenetic evidence, the two strains $Z X M 100^{\mathrm{T}}$ and ZXM098 should be classified as representatives of a novel species in a new genus in the family Rhodobacteraceae, for which the name Lentibacter algarum gen. nov., sp. nov. is proposed.

\section{Description of Lentibacter gen. nov.}

Lentibacter (Len.ti.bac'ter. L. adj. lentus slow; N.L. masc. n. bacter a rod; N.L. masc. n. Lentibacter a slow-growing rod bacterium).

Cells are Gram-negative and aerobic with no flagella. Colonies are colourless. Growth temperature range is narrow and growth occurs very slowly. Growth occurs in media containing $3-9 \% \mathrm{NaCl}$. Cells do not contain Bchl $a$. PHB is accumulated. Oxidase and catalase are positive. Cannot oxidize sulfite to sulfate. Nitrate is reduced to nitrite. $\mathrm{C}_{18: 1} \omega 7 c, \mathrm{C}_{18: 0}$ and $\mathrm{C}_{16: 0}$ are the major fatty acid components. The polar lipids are phosphatidylglycerol, phosphatidylethanolamine, phosphatidylcholine, a single lipid and an unidentified aminolipid. The predominant respiratory quinone is Q-10. The type species is Lentibacter algarum.

\section{Description of Lentibacter algarum sp. nov.}

Lentibacter algarum (al'ga.rum. L. gen. pl. n. algarum of/ from sea-weeds, isolated from Qingdao, China).

In addition to the characteristics that define the genus, the following characteristics are observed. Cells are ovoid to

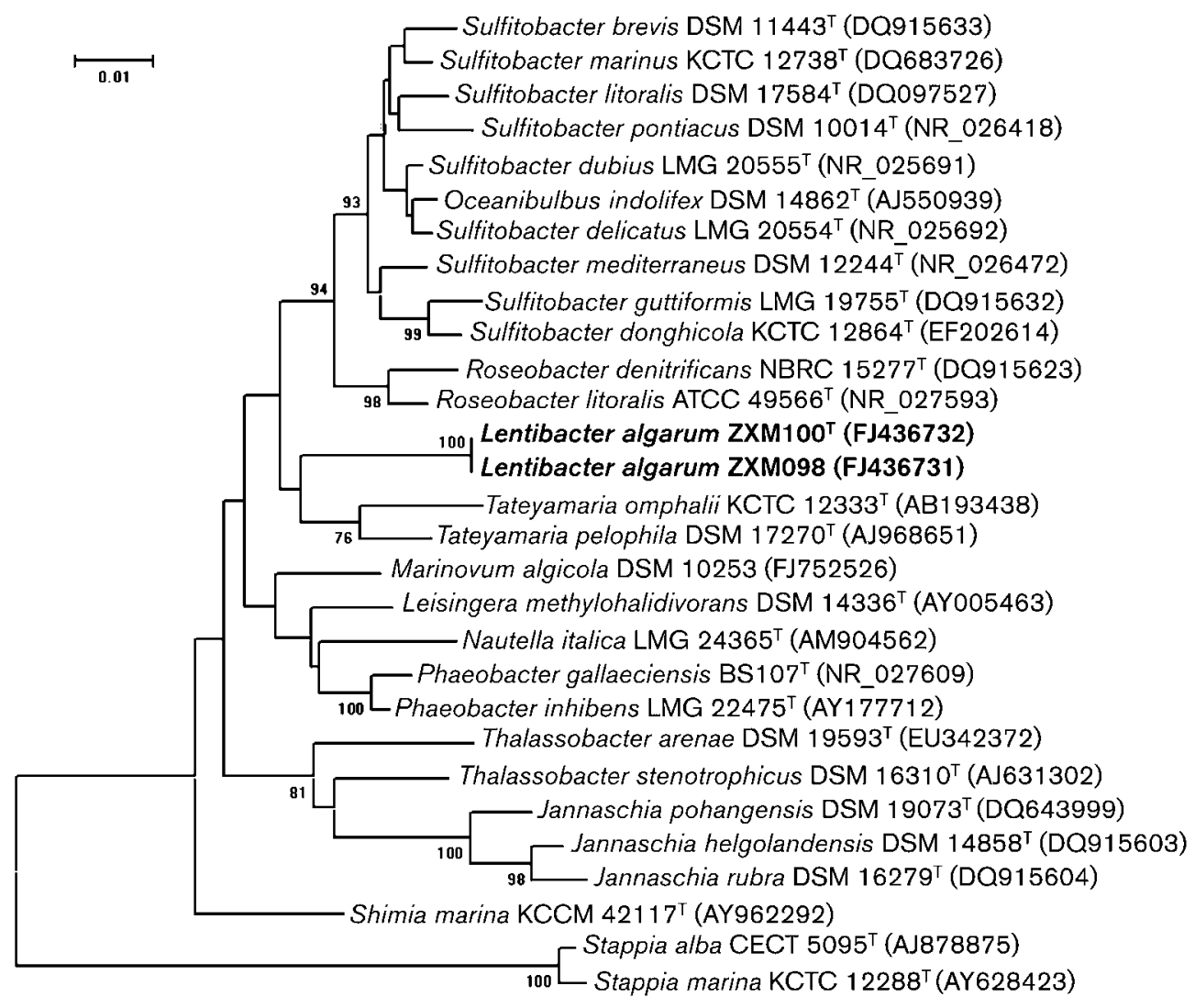

Fig. 2. Phylogenetic dendrogram of Lentibacter algarum $Z X M 100^{\top}, Z X M 098$ and strains of related species based on $16 S$ rRNA gene sequence similarities. The tree was constructed using the neighbour-joining method with Kimura 2-state parameter model analyses implemented in the program MEGA version 5. Bar, 0.01 nt substitutions per site. 
irregular short rods, approximately $1.0-3.0 \mu \mathrm{m}$ long by $0.8-1.0 \mu \mathrm{m}$ wide. Does not form endospores. Colonies are uniformly round, $0.2-1.0 \mathrm{~mm}$ in diameter, regular, convex and smooth. Grows on NA and forms colourless colonies; cannot grow on TSA. No diffusible pigment is produced in the medium.

The temperature range for growth is $22-28{ }^{\circ} \mathrm{C}$. The $\mathrm{pH}$ range for growth is 2.0-9.0. Hydrolysis of Tween 80 is strain-dependent (positive for type strain). Gelatin, agar, starch, casein and alginate are not hydrolysed. Antibiotic susceptibilities (amount of antibiotic/diameter of inhibition zone) are as follows: susceptible to vancomycin $(30 \mu \mathrm{g} / 28 \mathrm{~mm})$, erythromycin $(15 \mu \mathrm{g} / 54 \mathrm{~mm})$, ampicillin $(10 \mu \mathrm{g} / 19 \mathrm{~mm})$ and carbenicillin $(100 \mu \mathrm{g} / 29 \mathrm{~mm})$; slightly susceptible to benzylpenicillin (10 IU/24 mm); resistant to polymyxin B (100 IU/0 mm), gentamicin $(10 \mu \mathrm{g} / 10 \mathrm{~mm})$, kanamycin $(30 \mu \mathrm{g} / 0 \mathrm{~mm})$, tetracycline $(30 \mu \mathrm{g} / 0 \mathrm{~mm})$, neomycin $(30 \mu \mathrm{g} / 0 \mathrm{~mm})$ and oxacillin $(1 \mu \mathrm{g} / 0 \mathrm{~mm})$.

According to API 20E: $\beta$-galactosidase-positive; negative for arginine dihydrogenase, lysine decarboxylase, ornithine decarboxylase and tryptophan deaminase; citrate is utilized; $\mathrm{H}_{2} \mathrm{~S}$ and indole are not produced; urease and VogesProskauer reaction are strain-dependent (positive for type strain); produces acid from D-glucose, D-mannitol and sucrose; does not produce acid from inositol, D-sorbitol, Lrhamnose, melibiose, amygdalin or L-arabinose. According to API 20NE: aesculin ferric citrate is degraded; D-glucose is oxidized; $\mathrm{N}$-acetylglucosamine, potassium gluconate, capric acid, adipic acid, malic acid, trisodium citrate and phenylacetic acid are not utilized; and maltose is weakly utilized; D-mannitol, L-arabinose and D-mannose oxidation are strain-dependent (positive for the type strain). According to API ZYM, alkaline phosphatase, esterase (C4), esterase lipase (C8), leucine arylamidase, acid phosphatase and naphthol-AS-BI-phosphohydrolase are positive; lipase (C14), valine arylamidase, cystine arylamidase, trypsin, $\alpha$ chymotrypsin, $\alpha$-galactosidase, $\beta$-glucosidase, $\beta$-glucuronidase, $\alpha$-glucosidase, $\beta$ - $N$-acetylglucosaminidase, $\alpha$-mannosidase and $\alpha$-fucosidase are negative. According to API $50 \mathrm{CH}$, glycerol, D-xylose, arbutin, aesculin ferric citrate, cellobiose, sucrose, melezitose, turanose, gluconate, 2-ketogluconate and 5-ketogluconate are oxidized; D-galactose, D-fructose, maltose, amygdalin, glycogen, gentiobiose and D-lyxose are only oxidized weakly. According to Biolog, glycogen, Tween 40 , Tween 80, L-arabinose, cellobiose, $\alpha$-D-glucose, Dmannose, sucrose, turanose, citric acid, formic acid, $\alpha$ hydroxybutyric acid, $\beta$-hydroxybutyric acid, $\alpha$-ketovaleric acid, DL-lactic acid, L-phenylalanine and glycerol are oxidized; D-fructose, D-galactose, gentiobiose, maltose, succinic acid monomethyl ester and L-alaninamide are only weakly oxidized.

Of the 11 identified fatty acids in the type strain, $\mathrm{C}_{18: 1} \omega 7 \mathrm{c}$ is the major component, with smaller amounts of $\mathrm{C}_{18: 0}$ and $\mathrm{C}_{16: 0} . \mathrm{C}_{17: 0}, \mathrm{C}_{16: 1} \omega 7 c$ and/or $\mathrm{C}_{16: 1} \omega 6 c, \mathrm{C}_{10: 0} 3-\mathrm{OH}$ and $\mathrm{C}_{18: 1} \omega 07 c 11$-methyl are present as minor components. Other cellular fatty acids present at levels greater than $1 \%$ include $\mathrm{C}_{14: 0}, \mathrm{C}_{17: 1} \omega 8 c, \mathrm{C}_{18: 1} \omega 9 c$, unknown $\mathrm{C}_{18.846}$ and/or $\mathrm{C}_{19: 1} \omega 6 c$.

The type strain, strain ZXM100 ${ }^{\mathrm{T}}\left(=\mathrm{LMG} 24861^{\mathrm{T}}=\mathrm{CGMCC}\right.$ $\left.1.10234^{\mathrm{T}}\right)$, and one additional strain [ZXM098 $(=\mathrm{DSM}$ $24677=$ CGMCC 1.8996)] were isolated from seawater collected from a coastal region of Qingdao, PR China, during a massive green algae (Enteromorpha prolifera) bloom.

\section{Acknowledgements}

This work was supported by a grant from the National High Technology Research and Development Program of China (863 Program, no. 2007AA09Z434) and a grant from the National Natural Science Foundation of China (no. 40876067).

\section{References}

Beveridge, T. J., Lawrence, J. R. \& Murray, R. G. E. (2007). Sampling and staining for light microscopy. In Methods for General and Molecular Microbiology, pp. 19-33. Edited by C. A. Reddy, T. J. Beveridge, J. A. Breznak, G. Marzluf, T. M. Schmidt \& L. R. Snyder. Washington, DC: American Society for Microbiology.

Bosshard, P. P., Santini, Y., Grüter, D., Stettler, R. \& Bachofen, R. (2000). Bacterial diversity and community composition in the chemocline of the meromictic alpine Lake Cadagno as revealed by 16S rDNA analysis. FEMS Microbiol Ecol 31, 173-182.

Breznak, J. A. \& Costilow, R. N. (1994). Physicochemical factors in growth. In Methods for General and Molecular Bacteriology, pp. 137-154. Edited by P. Gerhardt, R. G. E. Murray, W. A. Wood \& N. R. Krieg. Washington, DC: American Society for Microbiology.

Buchan, A., González, J. M. \& Moran, M. A. (2005). Overview of the marine Roseobacter lineage. Appl Environ Microbiol 71, 5665-5677.

Choi, D. H. \& Cho, B. C. (2006). Shimia marina gen. nov., sp. nov., a novel bacterium of the Roseobacter clade isolated from biofilm in a coastal fish farm. Int J Syst Evol Microbiol 56, 1869-1873.

Chun, J., Lee, J.-H., Jung, Y., Kim, M., Kim, S., Kim, B. K. \& Lim, Y. W. (2007). EzTaxon: a web-based tool for the identification of prokaryotes based on $16 \mathrm{~S}$ ribosomal RNA gene sequences. Int J Syst Evol Microbiol 57, 2259-2261.

Gao, J., Pan, H., Xiao, T., Barbier, G., Wang, Z., Yue, H., Sun, S., Nitsche, S., Bernadac, A. \& other authors (2006). Isolation and characterization of novel marine Roseobacter clade members producing unique intracellular chromium-rich aggregates. Res Microbiol 157, 714-719.

Ivanova, E. P., Gorshkova, N. M., Sawabe, T., Zhukova, N. V., Hayashi, K., Kurilenko, V. V., Alexeeva, Y., Buljan, V., Nicolau, D. V. \& other authors (2004). Sulfitobacter delicatus sp. nov. and Sulfitobacter dubius sp. nov., respectively from a starfish (Stellaster equestris) and sea grass (Zostera marina). Int J Syst Evol Microbiol 54, 475-480.

Kim, B.-Y., Weon, H.-Y., Son, J.-A., Lee, C.-M., Hong, S.-B., Jeon, Y.-A., Koo, B.-S. \& Kwon, S.-W. (2009). Thalassobacter arenae sp. nov., isolated from sea sand in Korea. Int J Syst Evol Microbiol 59, 487490.

Kurahashi, M. \& Yokota, A. (2007). Tateyamaria omphalii gen. nov., sp. nov., an $\alpha$-Proteobacterium isolated from a top shell Omphalius pfeifferi pfeifferi. Syst Appl Microbiol 30, 371-375.

Labrenz, M., Tindall, B. J., Lawson, P. A., Collins, M. D., Schumann, P. \& Hirsch, P. (2000). Staleya guttiformis gen. nov., sp. nov. and Sulfitobacter brevis sp. nov., $\alpha$-3-Proteobacteria from hypersaline, 
heliothermal and meromictic antarctic Ekho Lake. Int J Syst Evol Microbiol 50, 303-313.

Lafay, B., Ruimy, R., Rausch de Traubenberg, C., Breittmayer, V., Gauthier, M. J. \& Christen, R. (1995). Roseobacter algicola sp. nov., a new marine bacterium isolated from the phycosphere of the toxinproducing dinoflagellate Prorocentrum lima. Int J Syst Bacteriol $\mathbf{4 5}$ 290-296.

Lyman, J. \& Fleming, R. H. (1940). Composition of seawater. J Mar Res 3, 134-146.

Macián, M. C., Arahal, D. R., Garay, E., Ludwig, W., Schleifer, K. H. \& Pujalte, M. J. (2005). Thalassobacter stenotrophicus gen. nov., sp. nov., a novel marine $\alpha$-proteobacterium isolated from Mediterranean sea water. Int J Syst Evol Microbiol 55, 105-110.

Martens, T., Heidorn, T., Pukall, R., Simon, M., Tindall, B. J. \& Brinkhoff, T. (2006). Reclassification of Roseobacter gallaeciensis RuizPonte et al. 1998 as Phaeobacter gallaeciensis gen. nov., comb. nov., description of Phaeobacter inhibens sp. nov., reclassification of Ruegeria algicola (Lafay et al. 1995) Uchino et al. 1999 as Marinovum algicola gen. nov., comb. nov., and emended descriptions of the genera Roseobacter, Ruegeria and Leisingera. Int J Syst Evol Microbiol 56, 1293-1304.

Mesbah, M., Premachandran, U. \& Whitman, W. B. (1989). Precise measurement of the $\mathrm{G}+\mathrm{C}$ content of deoxyribonucleic acid by highperformance liquid chromatography. Int J Syst Bacteriol 39, 159-167.

Park, J. R., Bae, J. W., Nam, Y.-D., Chang, H.-W., Kwon, H.-Y., Quan, Z.-X. \& Park, Y.-H. (2007). Sulfitobacter litoralis sp. nov., a marine bacterium isolated from the East Sea, Korea. Int J Syst Evol Microbiol 57, 692-695.

Pujalte, M. J., Macián, M. C., Arahal, D. R. \& Garay, E. (2005). Thalassobacter stenotrophicus Macián et al. 2005 is a later synonym of Jannaschia cystaugens Adachi et al. 2004, with emended description of the genus Thalassobacter. Int J Syst Evol Microbiol 55, 1959-1963.

Pukall, R., Buntefuss, D., Frühling, A., Rohde, M., Kroppenstedt, R. M., Burghardt, J., Lebaron, P., Bernard, L. \& Stackebrandt, E. (1999). Sulfitobacter mediterraneus sp. nov., a new sulfite-oxidizing member of the $\alpha$-Proteobacteria. Int J Syst Bacteriol 49, 513-519.

Ruiz-Ponte, C., Cilia, V., Lambert, C. \& Nicolas, J. L. (1998). Roseobacter gallaeciensis sp. nov., a new marine bacterium isolated from rearings and collectors of the scallop Pecten maximus. Int J Syst Bacteriol 48, 537-542.

Sass, H., Köpke, B., Rütters, H., Feuerlein, T., Dröge, S., Cypionka, H. \& Engelen, B. (2010). Tateyamaria pelophila sp. nov., a facultatively anaerobic alphaproteobacterium isolated from tidal-flat sediment, and emended descriptions of the genus Tateyamaria and of Tateyamaria omphalii. Int J Syst Evol Microbiol 60, 1770-1777.

Sasser, M. (1990). Identification of bacteria by gas chromatography of cellular fatty acids, MIDI Technical Note 101. Newark, DE: MIDI Inc.

Schaefer, J. K., Goodwin, K. D., McDonald, I. R., Murrell, J. C. \& Oremland, R. S. (2002). Leisingera methylohalidivorans gen. nov., sp. nov., a marine methylotroph that grows on methyl bromide. Int J Syst Evol Microbiol 52, 851-859.

Shiba, T. (1991). Roseobacter litoralis gen. nov., sp. nov., and Roseobacter denitrificans sp. nov., aerobic pink-pigmented bacteria which contain bacteriochlorophyll a. Syst Appl Microbiol 14, 140-145.

Smibert, R. M. \& Krieg, N. R. (1994). Phenotypic characterization. In Methods for General and Molecular Bacteriology, pp. 607-654. Edited by P. Gerhardt, R. G. E. Murray, W. A. Wood \& N. R. Krieg. Washington, DC: American Society for Microbiology.

Sorokin, D. Y. (1995). Sulfitobacter pontiacus gen. nov., sp. nov. - a new heterotrophic bacterium from the Black Sea, specialized on sulfite oxidation. Microbiology (English translation of Mikrobiologiia) 64, 295-305.

Tamura, K., Dudley, J., Nei, M. \& Kumar, S. (2007). MEGA4: molecular evolutionary genetics analysis (MEGA) software version 4.0. Mol Biol Evol 24, 1596-1599.

Thompson, J. D., Gibson, T. J., Plewniak, F., Jeanmougin, F. \& Higgins, D. G. (1997). The CLUSTAL_X windows interface: flexible strategies for multiple sequence alignment aided by quality analysis tools. Nucleic Acids Res 25, 4876-4882.

Tindall, B. J. (1990a). A comparative study of the lipid composition of Halobacterium saccharovorum from various sources. Syst Appl Microbiol 13, 128-130.

Tindall, B. J. (1990b). Lipid composition of Halobacterium lacusprofundi. FEMS Microbiol Lett 66, 199-202.

Tindall, B. J., Sikorski, J., Smibert, R. M. \& Krieg, N. R. (2007). Phenotypic characterization and the principles of comparative systematics. In Methods for General and Molecular Microbiology, pp. 330-393. Edited by C. A. Reddy, T. J. Beveridge, J. A. Breznak, G. Marzluf, T. M. Schmidt \& L. R. Snyder. Washington, DC: American Society for Microbiology.

Vandecandelaere, I., Nercessian, O., Segaert, E., Achouak, W., Mollica, A., Faimali, M. \& Vandamme, P. (2009). Nautella italica gen. nov., sp. nov., isolated from a marine electroactive biofilm. Int J Syst Evol Microbiol 59, 811-817.

Wagner-Döbler, I., Rheims, H., Felske, A., El-Ghezal, A., FladeSchröder, D., Laatsch, H., Lang, S., Pukall, R. \& Tindall, B. J. (2004). Oceanibulbus indolifex gen. nov., sp. nov., a North Sea alphaproteobacterium that produces bioactive metabolites. Int J Syst Evol Microbiol 54, 1177-1184.

Yoon, J. H., Kang, S. J., Lee, M. H. \& Oh, T. K. (2007a). Description of Sulfitobacter donghicola sp. nov., isolated from seawater of the East Sea in Korea, transfer of Staleya guttiformis Labrenz et al. 2000 to the genus Sulfitobacter as Sulfitobacter guttiformis comb. nov. and emended description of the genus Sulfitobacter. Int J Syst Evol Microbiol 57, 1788-1792.

Yoon, J. H., Kang, S. J. \& Oh, T. K. (2007b). Sulfitobacter marinus sp. nov., isolated from seawater of the East Sea in Korea. Int J Syst Evol Microbiol 57, 302-305. 